\title{
'I Would Have Gone on with the Hunger Strike, but Force-Feeding I Could Not Take': The Coercion of Hunger Striking Convict Prisoners, 1913-72
}

Do prison doctors force-feed to save lives or to punish? The answer to this is unclear. In reality, it seems likely that doctors hold differing views on the ethics of force-feeding. Their opinions might also depend upon the particular context in which they perform force-feeding. This chapter argues that, regardless of intention, force-feeding has proven itself in the past to be a remarkably effective weapon for stamping out hunger strikes. In December 2005, Guantánamo received a delivery of mobile restraint chairs, similar to those used in maximum-security prisons for violent mentally ill patients. Previously, Guantánamo detainees had been nasally fed. However, this new method of feeding involved strapping prisoners to a chair and inserting a forty-three inch tube through the body twice a day. It was infinitely more uncomfortable than nasal feeding. The number of detainees on hunger strike dropped swiftly from twenty-four to six. ${ }^{1}$ Even if prison doctors do genuinely believe it is their ethical duty to save lives, stomach tube feeding clearly serves a purpose in quelling prison protests, adding to the sense of physical and mental discipline felt by prisoners.

Exploring the experiences of force-fed twentieth-century convict prisoners can shed light on this matter. In 1913, the Prison Commissioners of England and Wales began to maintain a register of hunger strikes in English prisons. The Commissioners meticulously recorded prisoner motivations for hunger striking, the methods used by prison doctors to deal with food refusal, and the prisons in which protests took place. Initially, the Commissioners' register was intended as an inventory of non-political 
hunger strikes. Accordingly, they refrained from recording suffragette hunger strikes, although Irish republicans imprisoned in England occasionally seeped into the register. This imperative to record non-political protests alone presumably stemmed from anxiety about the prospect of convict prisoners attempting to use the Cat and Mouse Act-implemented in the same year as the register began-to secure premature release after witnessing the efficacy of militant suffragettes in gaining temporary freedom by refusing food. ${ }^{2}$ In 1913, one convict prisoner, Albert Davis, died in Bedford Gaol during a hunger strike inspired by the suffragettes. Shortly after, the Prison Commissioners amended their rules on reporting incidences of food refusal. ${ }^{3}$

The Prison Commissioners stopped recording entries in 1940 as space ran out in the pages of their register. Yet between 1913 and 1940, they made note of 834 prisoners who went on hunger strike. Collectively, these prisoners staged 1,188 hunger strikes. Only forty were IRA members, leaving a remainder of 794 convict prisoners with no obvious political affiliation. In twentieth-century England, hunger striking maintained a notable presence as an expression of remonstration that disrupted the normal disciplinary workings of penal institutions and challenged established power relations between staff and prisoners. Hunger strikes peaked between 1918 and 1921, and again between 1939 and 1940, due to the presence of Irish republican prisoners in English prisons. Nonetheless, in the intermittent period, the Commissioners recorded an average of 27.7 prison hunger strikes per year. ${ }^{4}$ Between 1940 and the mid-1970s, newspapers continued to report incidences of prison hunger striking, indicating that prisoners continued to refuse food throughout much of the century. This points to an important legacy left by the suffragettes and Irish republicans: their demonstration of the potency of food refusal to rebel against prison life.

James Vernon has emphasised the powerful role of hunger striking in defying the state and formulating political critique. ${ }^{5}$ Nonetheless, prisoners also refused food to address concerns relating to deplorable institutional conditions and a loss of rights. The erosion of personal rights that was intrinsic to the rapid rise of the disciplinary prison in the nineteenth century — starkly characterised by silence, solitude, and discipline-created a milieu in which prison staff tended to disregard prisoner complaints and deny inmates opportunities to protest against aspects of their imprisonment. As this chapter demonstrates, convict hunger strikes were often predicated upon re-asserting individual rights in an institutional setting 
that hinged upon conformity, reform, and strict behavioural control. Many prisoners who abstained from food did so in response to issues such as poor quality diet or harsh punitive treatment. They sensed an inherent inequity in place and sought to redress that imbalance by simply refusing to eat. Yet the modern prison, by its very nature, discouraged, and sought to suppress, the notion that prisoners could input into, or rally against, the conditions of their incarceration. ${ }^{6}$ Food refusal threatened institutional order by granting prisoners the autonomy to dictate how they interacted with the prison environment.

Medical staff preferred to force-feed rather than address prisoner concerns. In the public imagination, force-feeding is most commonly associated with the suffragettes and, in Ireland, with Thomas Ashe. However, in England, the practice remained in force as a coercive disciplinary technique throughout much of the twentieth century. If anything, the mass hunger strikes staged in the 1910s demonstrated the coercive value of stomach and nasal tubes in subduing recalcitrant prisoners. In their register, the Commissioners carefully noted whether hunger strikers had been forcefed; if so, how many times; and the instrument that had been used to feed. Between 1913 and 1940, the Commissioners recorded a total of 7734 force-feedings. ${ }^{7}$ In the post-war period, newspapers published accounts of hunger striking and force-feeding with rising frequency. Thomas Ashe's 1917 prison death following a fatal bout of force-feeding should not be understood as a controversial watershed that resulted in the discontinuance of prison feeding practices, as is often presumed to be the case. ${ }^{8}$ On the contrary, as this chapter demonstrates, the history of force-feeding can be re-assessed to account for the sustained use of feeding technologies on convict prisoners.

In turn, this raises important questions about the function of twentiethcentury prison medicine in regulating personal behaviour, maintaining prison order, and imposing discipline on the body. Twentieth-century English prisons remained modelled upon Victorian principles of deterrence and character reform. ${ }^{9}$ In the previous century, reformers had dramatically re-designed the prison, replacing a somewhat chaotic nationwide penal system with a rationalised, uniform prison network. Although predicated on humanitarian grounds, the reformed prison was notorious for the strict imposition of disciplinary regimes, including severe dietary restrictions, eighteen-month periods of solitary confinement and imposed silence. ${ }^{10}$ Michel Foucault argued that the modern period witnessed a shift from inflicting punishment on the body (by whipping and chaining) to 
regulating the mind (through psychological mechanisms such as the silent system). ${ }^{11}$ The criminal body-once subject to hanging and dismemberment-became exposed to less overtly physical methods of punishment. ${ }^{12}$ When prison officials decided to touch the body, it was to reach something inside - perhaps the 'soul', as Foucault claimed-but certainly the mind. ${ }^{13}$ Indeed, the ongoing use of physical punishments such as force-feeding confirms the more nuanced suggestion that physical and psychological punishment co-existed in the modern prison. ${ }^{14}$ Force-feeding seems to have been resorted to with the primary aim of 'rectifying' the behaviour of rebellious prisoners.

\section{Prison Hunger Strikes and Force-Feeding, C. $1913-40$}

[Hunger strikes are] very rarely carried through by criminals as a protest against physical misery imposed by prison conditions or prison discipline; for, however great the hardships of their lot may be, these are only intensified by the pains of starvation and the prospect of a lingering death. The hunger strike can be carried out only by men and women of iron will and endurance who feel themselves to be fortified by the strength of an inward conviction and are driven to use this weapon (whose point is directed upon their own heart) by the sense that for others, as well as for themselves, they have to protest against intolerable injustice and against moral and spiritual as well as physical cruelty. ${ }^{15}$

In 1929, WSPU treasurer Emmeline Pethick-Lawrence published this statement in The Guardian while reflecting on the suffragette hunger strike campaign. Emmeline perceptively recognised that hunger strikes are most effective when staged by an organised, mutually supportive unit of prisoners who share a common moral cause. She also pointed to a perceived sense of injustice-strengthened by perceptions of institutional cruelty - that, in her opinion, underpinned most decisions to abstain from food. Is Pethick-Lawrence's statement supported by later twentieth-century evidence? Why did twentieth-century convict prisoners hunger strike? What motivated them? And how successful were their protests?

Between 1913 and 1940, prison medical officers responded to 571 (52.5\%) hunger strikes with force-feeding. It can be reasonably assumed that medical staff threatened a significant number of other hunger strik- 


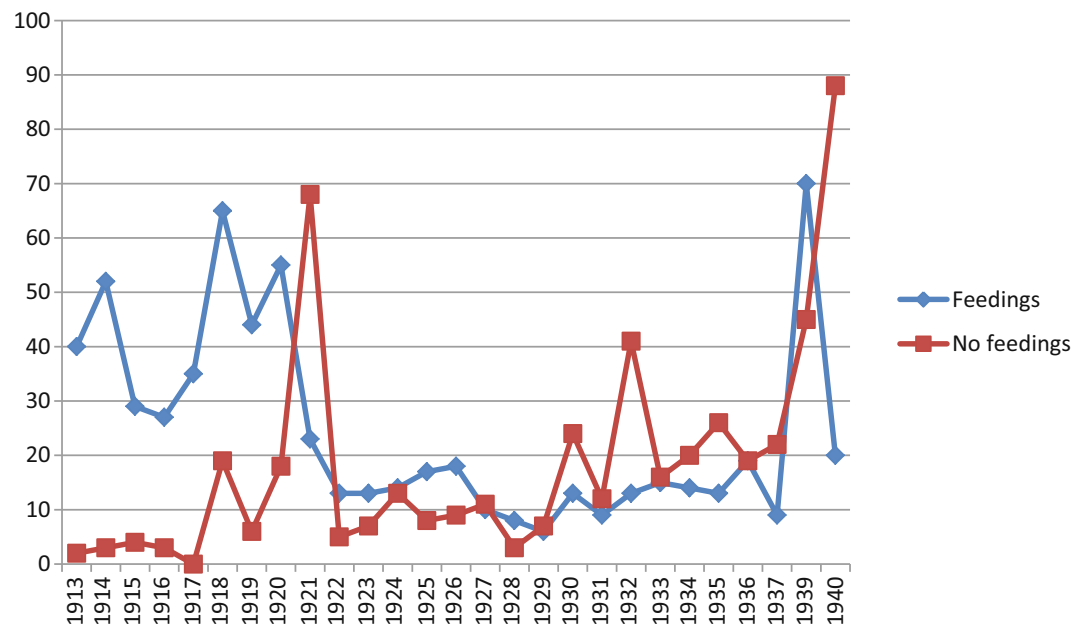

Fig. 6.1 Number of recorded hunger strike incidences responded to, and not responded to, with force-feeding in English Prisons, 1913-40 (Source: Kew, PCOM 2/465, 'Register of Criminal Prisoners on Hunger Strike (other than Suffragettes)', 1913-40)

ers with feeding technologies, successfully undermining their protests. It seems probable that more prisoners would have been fed had prison doctors deemed their health sufficient to withstand the procedure. Figure 6.1 details the number of force-feedings performed in prisons in this period and irrefutably discredits the presumption that prison staff stopped forcefeeding in 1917.

Importantly, force-feeding continued to be used in English prisons despite an awareness that the procedure could kill. When William Edward Burns died in Hull in 1918 after being fed against his will, the Home Office feared that public opinion would be inflamed and drawn towards the cause of conscientious objection in much the same way that Ashe's death had allowed Irish republicans to amass support for national independence. Private Home Office communication stated that:

This particular prisoner was certified to be in good general health and so presumably the operation of artificial feeding would be without physical detriment or danger, but the case has proved that even in the case of healthy subjects there is a contingent danger to life, though we cannot speak with certainty on this point until after the Coroner's inquest. If then, there is a 
contingent danger to life even in the case of those certified to be physically fit for the operation, it follows that the whole question of forcible-feeding in prisons must be raised and determined in light of this case, unless release from prison is to be the regular sequence of refusal to take food. ${ }^{16}$

Immediately after Burns' death, the Commissioners distributed a circular to all prisons advising that 'artificial feeding' should no longer be performed on conscientious objectors who should instead be temporarily released under the Cat and Mouse Act. ${ }^{17}$

Despite the well-publicised deaths of Thomas Ashe and William Edward Burns, force-feeding remained remarkably intact as a standard component of the prison doctor's arsenal for disciplining convict prisoners. Convict prisoners almost always initiated hunger strikes alone. Unlike the mobilised groups of suffragette and Irish republican prisoners who purposefully went on hunger strike en masse, convicts tended not to inspire other prisoners to sympathetically hunger strike. As William Murphy notes in relation to Ireland, hunger strikers without a firm cause or the support of their fellow prisoners rarely sustained their protests. ${ }^{18}$ Murphy's contention is borne out in twentieth-century English prison contexts.

To justify the ongoing use of force-feeding, the Commissioners routinely referred to the historical case of Leigh v Gladstone of 1909. As discussed in Chap. 2, this established legal precedence for the questionable argument that prison doctors were required to force-feed in line with their medical ethical duty to preserve health and save lives. ${ }^{19}$ This medicalisation of the hunger strike-now divorced from its political and institutional dimensions-ensured that food refusal continued to be designated as a medical concern long after the militant suffragette and Irish republican campaigns ended. From 1913, prison medical staff were obliged to report hunger strikes to the Commissioners (who, in turn, made a note in their register) and convey details of force-feeding. The Commissioners left the matter of whether hunger strikers were to be fed to the discretion of prison medical staff. ${ }^{20}$ Reinforcing a sense that hunger striking was a problem that demanded therapeutic intervention (as opposed to a valid form of protest), in January 1918, the Commissioners distributed a circular that clearly outlined their stance on the desirability of treating hunger strikers as hospital patients, either in the prison hospital or in their prison cells. ${ }^{21}$

Throughout the early twentieth century, the institutional role and influence of prison medical staff considerably expanded, in part because their expertise in criminology became highly valued both inside and outside of 
the institution. ${ }^{22}$ While it could be argued that prison doctors felt caught in a dual loyalty to their profession and their institutional workplace, Joe Sim maintains that many of them willingly, if not enthusiastically, contributed to the disciplinary ethos of prisons by enforcing prison regimen and inflicting punishment. Prison doctors developed an armoury of techniques designed to deal with troublesome prisoners and played an active role in maintaining institutional order. ${ }^{23}$

If anything, the frequent resort of English prison doctors to forcefeeding seems relatively unremarkable given that they regularly prescribed large quantities of psychotropic drugs to subdue unruly prisoners, removed parts of their prisoners' brains when performing surgical lobotomies, and used electro-convulsive therapy to modify seemingly disruptive behaviour patterns. ${ }^{24}$ Some post-war physicians hoped that increasingly sophisticated forms of bodily intervention would one day be developed to enhance the 'treatment' of crime in prisons. Hormones and pharmaceutical substances could be developed to reduce the numbers of sexual offenders; new brain surgery methods might be developed to modify anti-social behaviour; and medications might be produced to sedate criminals with violent tendencies. ${ }^{25}$ Others suggested that prisons could be transformed into therapeutic communities, a concept borrowed from post-war psychiatric thought that emphasised the value of techniques such as group counselling. ${ }^{26}$ What seems clear is that prison medical staff tended to view the imprisoned population as a consortium of individuals who refused to adapt themselves to a socially acceptable mode of living. ${ }^{27}$ This created a climate of thought that encouraged crime to be viewed as a personal disorder requiring rectification rather than a negative effect of environmental or social problems. Prison doctors saw their role as being to 'treat' the moral and psychological problem of criminality through processes of socialisation and behavioural normalisation. In this context, food refusal came to be frowned upon as a potent expression of behavioural disorder, a perspective that undermined any sense that a prisoner's grievances might, in some cases, be valid.

In the twentieth-century English prison, the boundaries between therapy and coercion remained remarkably fluid, reinforcing a sense felt among prisoners that prison medicine was central to the disciplining of the institutionalised body. It did not simply serve benevolent, healthimproving purposes. Indeed, the Prison Medical Service-autonomous from the broader national health system-came under increasing scrutiny precisely because of its penalising tendencies throughout the twentieth 
century, as evidenced by the publication of the Prison System Enquiry Committee's damning English Prisons Today in 1922 (led by Stephen Hobhouse and A. Fenner Brockway) and Roger Page's highly critical Prison Medical Service in $1943 .{ }^{28}$ Nonetheless, despite mounting public criticism, the role of prison medical staff continued to expand, particularly in the post-war period. ${ }^{29}$ The few individuals aware of the ongoing use of force-feeding commented on the coercive or careless intentions of those performing the procedure. In 1922, Hobhouse and Brockway reported that prison medical staff took the matter of force-feeding 'too lightly' and insisted that the procedure was performed with insufficient care and in spite of a broader consensus among physicians outside of the prison on its potential dangers. ${ }^{30}$ More assertively, in 1922, Mary Gordon published a critical account of her experiences as the first Lady Inspector of English Prisons, a post that she held between 1908 and 1921. In Penal Discipline, she asserted that:

An offender is sent to prison by the judge or magistrate so that he may undergo penal discipline which, with loss of liberty, is his punishment. Once in prison, if he attempts to do his own will, to offend against the prescribed order, to disobey, resist, or assault his gaolers, he can be punished again by the Governor or the Justices. He can be coerced or punished in various ways, by forfeiture of remission, loss of privilege, by dietary deprivations, by separate or close confinement. His body may be restrained, day and night, in irons, or tied up and flogged. He can be forcibly-fed (a treatment called medical, but in reality disciplinary) in order to prevent his determining his imprisonment. In short, we are not afraid to hurt, or injure, or cause him to run risks, in order to master him. ${ }^{31}$

Gordon equated force-feeding with brutality and identified the procedure as part of a broader web of coercion that was ultimately failing to rehabilitate and reform. She concluded that 'during my service I found nothing in the prison system to interest me, except as a gigantic irrelevance-a social curiosity. If the system had a good effect on any prisoner, I failed to mark it. I have no shadow of doubt of its power to demoralise, or of its cruelty. It appears to me not to belong to this time or civilisation at all. ${ }^{32}$

Prisoners undoubtedly struggled to challenge the imbalanced power systems that structured the twentieth-century prison. Only one recorded incidence exists of a force-fed prisoner taking legal action against prison medical staff. In March 1944, Frederick Bowman prosecuted Drs Grierson and Saville for having used force-feeding 'as a brutal form of unlawful 
punishment', maliciously exceeding their ethical duties, and committing professional misconduct by using an emergency medical procedure to torture and intimidate. To support these strong assertions, Frederick insisted that both doctors had uttered violent threats while feeding him, adding to an underlying sense of torment. Frederick had been detained under Regulation 18B of the Defences Regulation Acts of 1939. This Regulation stipulated that detainees were to be confined for custodial, not punitive, purposes and that their confinement should not be oppressive. Despite this, Grierson force-fed Frederick from the fifth day of his hunger strike, a decision which he subsequently justified with recourse to the argument that prison doctors had an ethical obligation to save lives.

As in the case of Leigh $v$ Gladstone, Bowman $v$ Grierson coalesced around the contested issue of whether force-feeding was therapeutic or coercive. It is impossible to decipher whether Frederick truly believed in the therapeutic benefits of force-feeding or if he chose to resuscitate a familiar medical argument to conceal his hostile behaviour. Nonetheless, the verdict supported the medical perspective and even concluded that the doctors had acted with great kindness towards their patient, not with vindictiveness. Grierson insisted that 'I had no thought of punishment or torture or intimidation. I only looked at it from the medical angle.' Both Grierson and Saville were cleared of assault. ${ }^{33}$ This outcome, which mirrored Mary Leigh's unsuccessful effort to prosecute the Home Secretary and her prison medical staff, reveals much about the power systems in place in the English penal network that worked against the concerns of aggrieved prisoners.

Nonetheless, evidence collated from the Commissioner's register adds weight to Bowman's claim that force-feeding was used principally to coerce and intimidate. Figure 6.2 outlines the number of force-feedings (in relation to individual hunger strikes) performed in English prisons between 1913 and 1940. The procedure clearly brought an overwhelming majority of hunger strikes to an abrupt end. $44 \%$ of hunger strikes (responded to with the stomach or nasal tube) were abandoned after one feeding. Only $28 \%$ lasted beyond a second feeding. As mentioned in the introduction, when Judith Todd, daughter of Rhodesia's former Prime Minister Garfield Todd was force-fed in 1972 (causing a public scandal), she announced, 'I couldn't take it. I failed. I would have gone on with the hunger strike, but force-feeding I could not take'. ${ }^{34}$ Todd's statement perhaps exemplifies the common experience of force-fed prisoners. Working on the presumption that hunger strikers were fed 3 times daily, $70 \%$ of force-fed hunger 


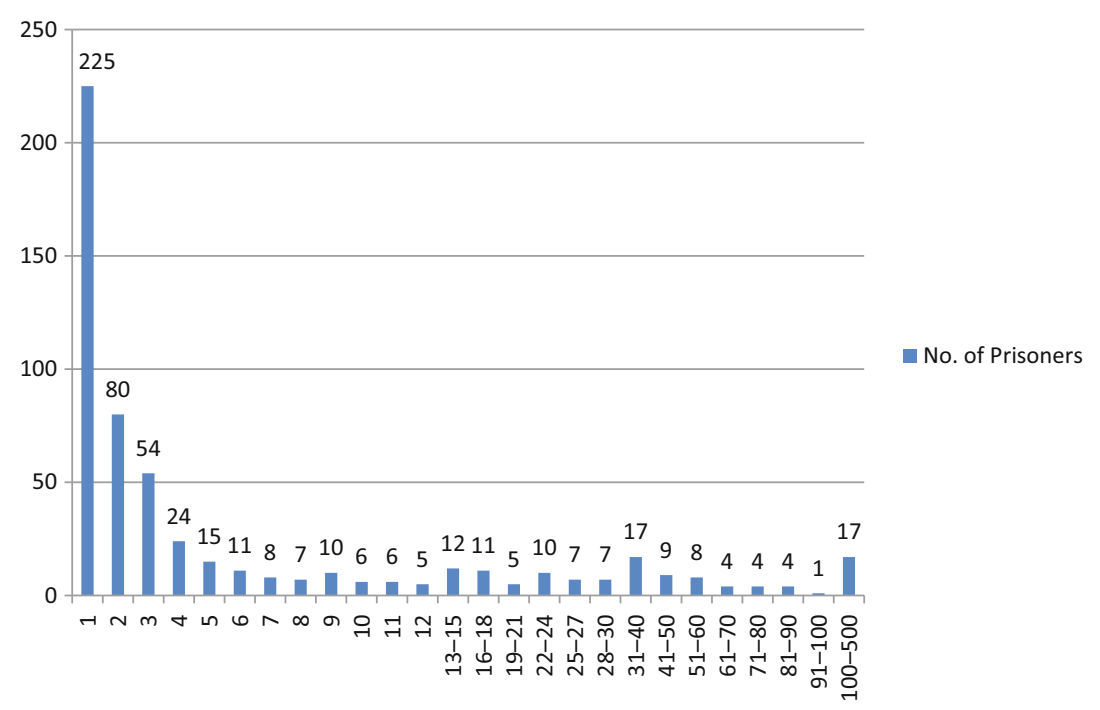

Fig. 6.2 Number of times prisoners were force-fed on individual hunger strikes in English prisons, 1913-40 (Source: Kew, PCOM 2/465, 'Register of Criminal Prisoners on Hunger Strike (other than Suffragettes)', 1913-40)

strikers abandoned their protest within a day. Only $30 \%$ persevered into a second day. $21 \%$ endured beyond two days. Evidently, force-feeding rapidly extinguished episodes of food refusal, quickly restored institutional order, and re-established the normal relationship between staff and prisoners. This suggests that force-feeding had disciplinary value and supports claims made by suffragettes and Irish republicans on the coercive nature of the procedure. Foucault maintained that an essence of torture remained in the modern prison system and it is conceivable that force-feeding was one technology of the body used to implement this. ${ }^{35}$

Moreover, and importantly, the tumultuous events of the Irish War of Independence had made clear that prisoners could abstain from food for around fifteen days without suffering permanent physical harm. However prison doctors tended to force-feed during the early stages of a hunger strike under the auspices of avoiding a looming death, despite a general awareness that human starvation tended not to occur so rapidly. Irish republicans had irrefutably demonstrated that death was unlikely to occur towards the start of a prison fast. The controversial death of Terence MacSwiney in 1920 had confirmed this point. Given the high 
public profile of this prison fatality, the Commissioners and prison staff would presumably have known that force-feeding early on was unnecessary. When viewed from this perspective, it seems plausible that prison medical staff understood that the lives of fasting prisoners were not in immediate danger but recognised that a short feeding period-often one feeding - swiftly ended most hunger strikes.

An underlying sense of coercion was further reinforced by the prison doctor's preference for using intrusive feeding technologies. Figure 6.3 indicates that the stomach or oesophageal tube was the preferred instrument of feeding. Feedings with nasal tubes, stomach pumps, and spoons occurred less frequently. Notably, in 1963, the British Medical Journal suggested that tube feeding was in fact viewed unfavourably in hospital practice due to an absence of standardisation and lack of attention paid to issues such as calorific intake. The journal commented that doctors used gastric tubes so infrequently in hospital practice that subclinical malnutrition was a common problem among patients undergoing prolonged convalescence. ${ }^{36}$ Nonetheless, feeding technologies retained an active purpose in both prison and asylum practice. In the interwar period, the feeding cups occasionally described in suffragette propaganda fell out of fashion,

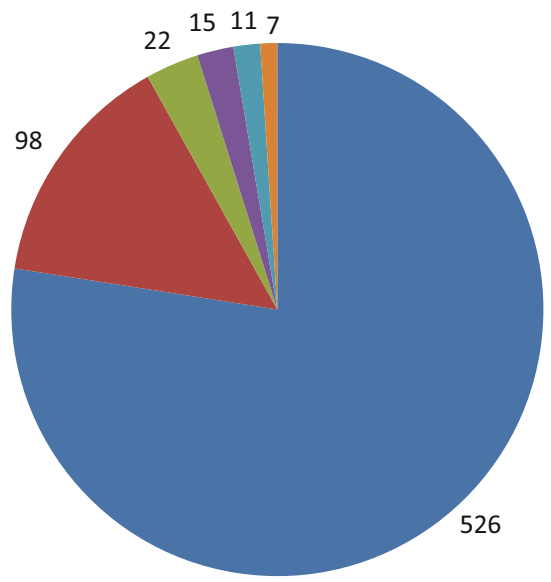

Stomach or Oesophagal Tube

Nasal tube

Spoon-fed

- Nasal and

Stomach/Oesophagal Tube

- Feeding Cup

- Stomach Pump

Fig. 6.3 Instruments used for force-feeding in English prisons, 1913-40 (Source: Kew, PCOM 2/465, 'Register of Criminal Prisoners on Hunger Strike (other than Suffragettes)', 1913-40) 
reflecting changing technological considerations in asylum practice. In his textbook Mind and its Disorders, published in 1926, psychiatrist William Henry Butter Stoddart asserted that the feeding cup was 'a pernicious utensil and a fertile source of pulmonary access and gangrene'. ${ }^{37}$ Two years earlier, Robert Henry Cole had commented in his Mental Diseases that asylum doctors rarely used stomach pumps to feed, instead preferring a soft rubber oesophageal tube. The oesophageal tube, Cole explained, was quicker and easier to use, an attraction for time-consumed, and perhaps impatient, prison doctors. Cole also noted that medical staff could introduce large quantities of semi-solid food into the body with oesophageal and stomach tubes, contrasting with the more cumbersome nasal tube that depended upon inserting liquids, irritated the patient's nasal mucous membrane, and were prone to becoming blocked. ${ }^{38}$ Nonetheless, gastric tubes were the most invasive of technological resources available, and therefore most feared by prisoners. Certainly, suffragette and Irish republican propaganda had focused on the horrors of the stomach tube more intently than the less intrusive, but labour-intensive, nasal tube. The physical invasiveness of gastric tube technologies no doubt reinforced the sense of intimidation felt by fasting prisoners.

Notably, the use of force-feeding was geographically evenly spread. Between 1913 and 1940 (and presumably beyond), the procedure was used almost universally in English prisons. In their register, the Commissioners recorded that force-feeding had been performed in fiftyone prisons. In 1913, England had a total of sixty-one prisons; a figure reduced to thirty-eight by 1940 . The almost universal use of force-feeding suggests that a consensus existed among prison medical staff on the usefulness of feeding in tempering protest. Figure 6.4 details the number of times force-feeding was performed in the nineteen prisons with the highest number of incidences. It demonstrates that hunger strikes were more likely to occur in prisons with higher bed numbers, naturally reflecting the larger number of prisoners resident in these institutions who might potentially refrain from eating. In 1913, Parkhurst Prison could accommodate up to 818 prisoners, an institution where force-feeding was performed 90 times. Prison doctors performed 71 force-feedings in Manchester Prison which could accommodate 1203 prisoners in 1913. Similarly, in 1913, Liverpool, Wormwood Scrubs, Pentonville, Dartmoor, and Wandsworth all contained over 1000 beds. With the exception of Wandsworth, over thirty hunger strikes were responded to with force-feeding in each of these institutions. This compares with smaller institutions such as Bristol 


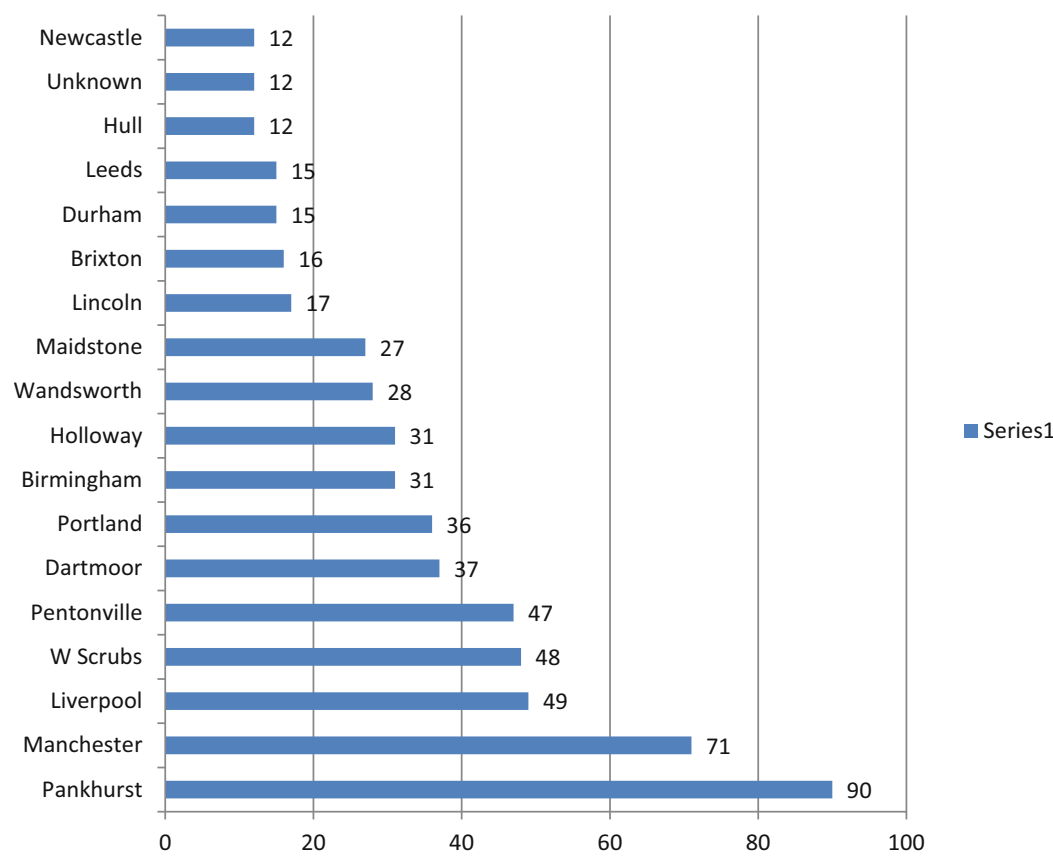

Fig. 6.4 English prisons in which incidences of force-feeding occurred, 1913-40 (Source: Kew, PCOM 2/465, 'Register of Criminal Prisoners on Hunger Strike (other than Suffragettes)', 1913-40)

Prison that could accommodate 303 prisoners and witnessed only 3 forcefeedings. Similarly, Exeter Prison could accommodate 185 prisoners, an institution where prison doctors performed 4 force-feedings. ${ }^{39}$

The number of force-feedings carried out in individual prisons inevitably depended upon the number of prisoners in residence who chose to hunger strike. Yet smaller prisons tended to be staffed by part-time medical officers. ${ }^{40}$ This contrasts with larger prisons such as Wormwood Scrubs that contained a specialised surgical unit, superior staffing arrangements, and even a psychiatric unit by the 1940s. ${ }^{41}$ Those prisons fortunate enough to contain sufficient medical resources and dedicated full-time staff were no doubt more able to use available resources to engage in prolonged feeding periods that, in extreme cases, involved three feedings each day for a number of months. The longest feeding periods typically took place in large institutions such as Wormwood Scrubs where, between 
1914 and 1915, a prisoner named Humphries was fed 290 times, a period of approximately 96 days. ${ }^{42}$

The overall impression that emerges from the Commissioner's register is that force-feeding remained relatively common in English prisons even despite the vivid accounts of brutality, pain, and psychological trauma that had been brought to public attention by militant suffragettes and the recommendations made against the practice in Ireland at the inquest that followed Ashe's death. A large proportion of hunger strikers were subjected to force-feeding; a procedure that brought their protests to an abrupt end, as evidenced by the vast majority of hunger strikes not lasting beyond a day of feeding. A preference for using intrusive technologies reinforced the sense of imposed discipline felt by protesting prisoners while, from the perspective of the prison doctor, strengthening their deterrent value. The use of force-feeding was geographically spread, although it was used most often in larger prisons equipped with extensive medical facilities. Legal action was rarely taken against prison doctors and proved unsuccessful.

\section{Why Hunger STRIKe?}

What motivated convict prisoners to hunger strike? In their register, the Commissioners recorded various reasons for refusing to eat. Post-war journalistic reportage sheds further light on the multiplicity of factors that encouraged hunger striking. Figure 6.5 collates the motivations noted by the Commissioners (no reason was recorded in 339 incidences or $29 \%$ of all hunger strikes). In 1920, medical staff at Liverpool Prison force-fed Michael Brennan 138 times. Throughout his forty-six days of being forcefed, Michael provided no rationale for refusing food. Incidences such as these provide the most puzzling accounts of hunger striking, although one plausible explanation is that prison staff sought to conceal sources of prisoner disgruntlement from the Commissioners. ${ }^{43}$

Moreover, the recorded motivations undoubtedly reflected the perceptions of institutional staff towards prisoners. While some reasons (such as conscientious objection) are relatively straightforward to decipher, vaguer explanations (such as malingering and suicidal tendencies) need to be cautiously interpreted as potential expressions of the derogatory attitudes of prison staff towards certain prisoners rather than accurate representations of personal motivations. The frequent assigning of mental illness as a rationale for hunger striking affirms this point. Between 1913 and 1940, the Commissioners noted seventy-eight hunger strikes somehow 


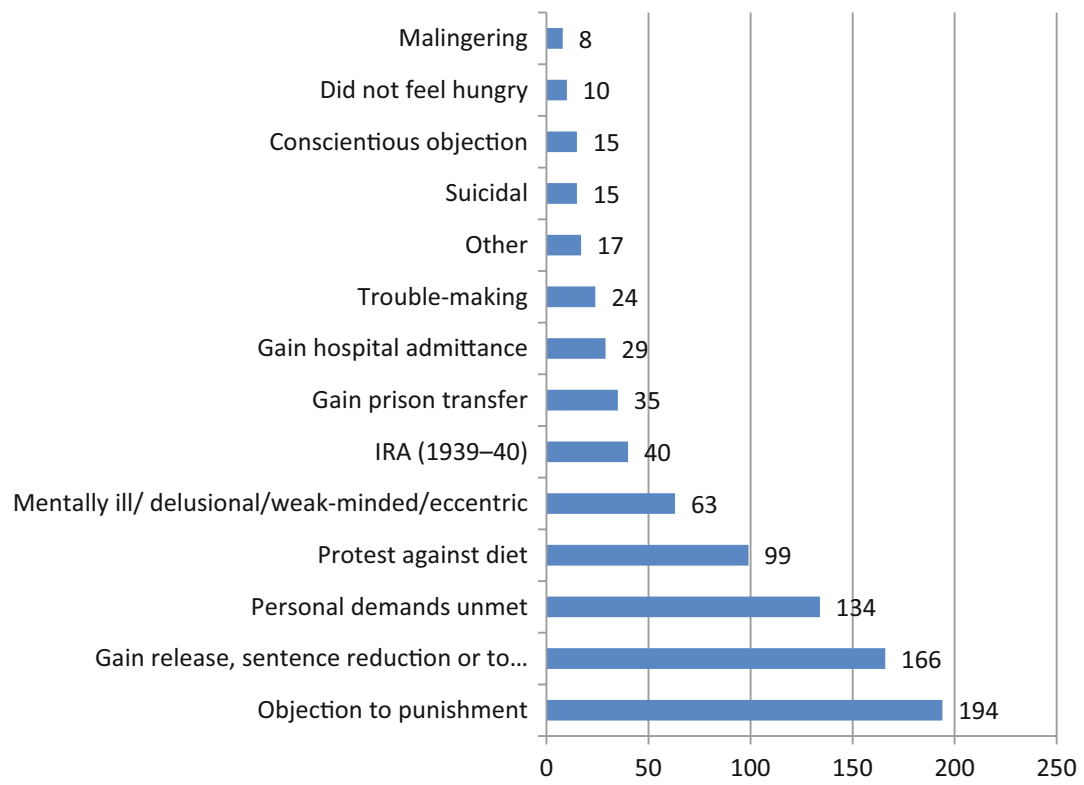

Fig. 6.5 Recorded motivations for hunger striking in English prisons, 1913-40 (Source: Kew, PCOM 2/465, 'Register of Criminal Prisoners on Hunger Strike (other than Suffragettes)', 1913-40)

connected to mental instability. ${ }^{44}$ Yet, historically, the labelling of mental disorder was framed by broader socio-cultural presumptions made by physicians about certain character types or social groups. In the 1910s, medical authors had condescendingly diagnosed militant suffragettes as hysteric to explain their uncharacteristic masculine tendencies towards violence ${ }^{45}$ When viewed retrospectively, this classification reveals more about the gendered perceptions of doctors who took to writing than the actual psychological condition of suffragettes.

Twentieth-century prison doctors increasingly involved themselves in the issue of mental health. In the previous century, the British medical community had expressed a growing concern with understanding the psychological makeup of criminals. They often depicted criminals as physically and psychologically different, as set apart from morally sound individuals by their physical and mental condition. ${ }^{46}$ In this context, prison medical staff found themselves well-positioned to observe and report on the psychological aspects of crime. ${ }^{47}$ Prison doctors tended not to be psy- 
chiatrically trained. Nonetheless, they routinely engaged in mental health diagnosis. ${ }^{48}$ They also shared a common propensity to label disruptive patients as insane to support ongoing confinement or to transfer bothersome inmates to an asylum. ${ }^{49}$ Yet by emphasising the natural mental predisposition of criminals prior to institutionalisation, medical staff proved less attentive to the potential psychological and emotional effects of the prison environment itself. ${ }^{50}$

In their register, the Commissioners recorded sixty-three hunger strikes seemingly connected to psychiatric disorders ranging from severe (suicidal) to mild (eccentricity). ${ }^{51}$ Many of these diagnoses were relatively vague, including 'delusional' or 'weak-minded'. ${ }^{52}$ Prison doctors designated suicidal impulse as the reasoning behind a further fifteen episodes of food refusal and insinuated that a number of other protestors harboured a desire for death. ${ }^{53}$ But, were convict hunger strikers suicidal? In 1918, Richard Pugh initiated a hunger strike at Winchester Prison due to 'the futility of things'. Richard was force-fed five times before prison officials transferred him to Pentonville Prison. At Pentonville, Richard initiated a second hunger strike brought to an end after three feedings. In 1929, prison doctors interpreted a hunger strike pursued by James Henry Marsh as an expression of his desire to die. James endured nine force-feedings before ending his protest. During the First World War, German prisoner of war Leopold Vieyra was force-fed thirty times in Pankhurst Prison after initiating a hunger strike reportedly connected to his mental depression. A further hunger striker stated that he was 'tired of coming to prison year after year and would be better dead' ${ }^{54}$

In reality, it seems highly unlikely that prisoners would have chosen self-starvation as a method of suicide. Suicidal prisoners ended their lives in far more determined ways. They attached themselves to gas brackets and asphyxiated themselves ${ }^{55}$ or hanged themselves in their cells with their belts. ${ }^{56}$ Speedier and more efficient options were available for prisoners who wished to end their life than a slow period of self-imposed starvation. ${ }^{57}$ Moreover, force-feeding was an inadequate response to mental depression. When viewed retrospectively, these remarks can be viewed as comments made by prisoners about the psychologically harmful effects of prison life interpreted, or presented, by prison doctors as expressions of suicidal intent. Undoubtedly, prison life had a wearing effect on mental health. Prison suicide persisted as a pertinent problem throughout the twentieth century. Yet prison doctors and politicians typically made recourse to the argument that higher levels of mental illness existed 
among criminal types, carefully skirting the issue of whether prison life itself fostered suicidal tendencies. ${ }^{58}$ In contrast, critics, such as Hobhouse and Brockway, insisted that environmental aspects of prison life played an equally important role in encouraging suicide. ${ }^{59}$ Nonetheless, prisoners were denied the opportunity to assert their right to live in humane conditions that did not tarnish their emotional well-being. Those who refused food on this basis were force-fed rather than offered psychiatric care.

On one occasion, the attribution of suicidal intent allowed prison doctors to cast blame for a death suspiciously associated with force-feeding on to a hunger striking prisoner. In 1912, Steinie Morrison arrived at Pankhurst Prison. Steinie had been convicted of murder and sentenced to death, although his sentence had been commuted to life imprisonment. Throughout almost a decade of imprisonment, he maintained his innocence. In 1921, Steinie died in Pankhurst Prison. At the inquest that followed, prison doctors recollected that Steinie refused food immediately upon arriving at the prison and needed to be restrained due to his violent tendencies and persistent suicide threats. At the inquest, the doctors suggested that Steinie had gradually reduced his food intake since 1917 with the intention of slowly ending his life. When doctors threatened him with a feeding cup, Steinie would intimate that he intended to cut his own throat. In response, prison medical staff had removed Steinie to a padded cell and regularly force-fed him; an act vigorously resisted by their patient. In 1921, Steinie died unexpectedly from a heart problem.

A coroner present at the inquest remained unconvinced that Steinie had died from years of gradually cutting back on food and refused to sanction the cause of Steinie's death to suicide through self-starvation. The jury returned a verdict of death from syncope and aortic disease aggravated by food abstinence. ${ }^{60}$ Evidently, the jury refused to fully take on board insinuations made by the prison medical staff about Steinie's suicidal intent. Yet the inquest is also noteworthy for the lack of scrutiny of the use of force-feeding and its potential role in undermining Steinie's health and precipitating a fatal heart condition (a link forged by militant suffragettes and Irish republicans). It is unclear whether the prison doctors knew full well that their feeding practices had weakened Steinie's heart. What is clear is that Steinie was a particularly troublesome and violent man who was out of favour with the prison doctors who, he claimed, regularly plied him with laxatives to incapacitate and punish him. ${ }^{61}$ Given that force-feeding held coercive purposes, it seems plausible that the procedure was regularly performed on him and played some role in his death. 
Depicting Steinie as suicidal allowed medical staff to present his death as an unfortunate outcome of his refusal to eat rather than their forceful attempts to feed him. Steinie's plight attracted comparatively little public attention in comparison to Thomas Ashe's politically charged death. Public sympathy was unlikely to be forthcoming for a convicted murderer. In fact, in this period, a relative lack of public sympathy towards nonpolitical hunger strikers allowed the use of coercive techniques to remain mostly hidden from public view, at least until the post-war period. Michael Ignatieff suggests that it was essential that the infliction of punishment conserved its moral legitimacy in the eyes of the public. ${ }^{62}$ In this instance, prison doctors achieved this by portraying Morrison as suicidal.

Prison doctors could not convincingly attribute all hunger strikes to mental illness. Many prisoners protested in objection to the physical ramifications of prison life, once again asserting their right to health. For instance, many revolted against the sparse dietary arrangements available, seeing this as a threat to their physical integrity. ${ }^{63}$ Between 1913 and 1940 , ninety-nine prisoners refused to eat in protest against the unpalatable diet on offer in prisons. A further ten simply stated that they did not feel hungry. The Commissioner's register is replete with brief statements made by prisoners who provided their reason for hunger striking as 'I can't eat that bread', 'I cannot eat it', and 'poison'. ${ }^{64}$ In 1921, John Moran abstained from eating in Pankhurst as he felt unable to face the inedible prison food. Denying John the right to express dissatisfaction with prison food quality, prison doctors force-fed him nineteen times before he decided to resume eating. Four years later, Thomas Jameson abstained from food for similar reasons and was force-fed twenty-six times. ${ }^{65}$

Prison dietaries were notoriously meagre, having been devised in the nineteenth century to deter criminal activity and contribute to the coercive ethos of the prison. Many officials insisted that prison diets needed to be punitive and advocated providing the bare minimum of food required by the human body to avoid death. ${ }^{66}$ In 1921, Evelyn Ruggles-Brise, Chairman of the Prison Commission, claimed that prison diets had dramatically improved since the Victorian period, meaning that prisoners no longer lost weight or became susceptible to illness. The principle of a punitive diet, he insisted, no longer existed.$^{67}$ In contrast, Hobhouse and Brockway retorted that prisoners felt perpetually hungry and that catering staff prepared meals using poor quality food items. Prisoners, they suggested, were worryingly prone to indigestion, diarrhoea, skin rashes, and constant constipation. ${ }^{68}$ In 1944, the Medical Research Council concluded 
that prison dietaries lacked Vitamins $\mathrm{A}$ and $\mathrm{C}$ and recommended fuller provisions. ${ }^{69}$ Three years later, 105 prisoners at Pankhurst Prison staged a mass protest related to poor quality food. ${ }^{70}$ Some improvements were made in 1959. ${ }^{71}$ Yet prison diets continued to spark debate. In 1972, Northern Irish MP, Bernadette Devlin, quizzed the Under-Secretary of State for Home Affairs, Mark Carlisle, on the amount being spent on food in prisons. It transpired that $£ 1.20$ a week was being spent on feeding prisoners in Leicester Prison, a figure that compared unfavourably to the $£ 2.50$ per week being spent buying food for the prison dogs. ${ }^{72}$

Given this context, it seems unsurprising that prisoners protested against sparse, often unpalatable, food provisions, sensing an undermining of their right to nutritional and physical health. However a small number of hunger strikes arose due to a lack of sensitivity among prison staff to certain dietary requirements or preferences. When conscientious objector Fenner Brockway was imprisoned in Wormwood Scrubs during the First World War and requested a vegetarian diet, the doctor shook his head. A change to the dietary arrangements was only allowed if a prisoner showed severe weight loss. Angered, Fenner petitioned the Home Secretary and began a partial hunger strike by refraining from eating meals containing meat. Approval of a vegetarian diet was granted three months later. According to Fenner, the vegetarian option proved popular among prisoners accustomed to eating coarse meat items. 'Hardened criminals', Fenner later claimed, 'including a man who was serving a year for hitting his wife on the head with a poker, assured the Governor that their consciences would no longer allow them to eat meat'. ${ }^{73}$ Notably, Fenner was opposed to the idea of threatening to take his own life on the grounds that he was a pacifist and should not kill anyone, even himself. ${ }^{74}$

Although most prisoner protests relating to food proved unnewsworthy, there was one exception. In 1974, the Daily Mirror reported on its front page that a hunger striking Jewish prisoner named Keith Baillie had been force-fed for a staggering 800 days. Keith was serving a fifteen-year sentence for robbery and firearm possession. He had initially refused to eat after catering staff accidentally served him kosher margarine on a spatula also being used to dispense non-kosher margarine. The prison officials swiftly rectified the catering situation. Nonetheless, Keith continued to protest and issued a writ to the Home Office demanding that the Commissioners enforce their own regulations and grant him the right to observe his religion. Prison medical staff transferred Keith to a psychiatric wing. Although Keith occasionally accepted food from a cup 
with a sprout, he was force-fed for over two years. ${ }^{75}$ When Keith's plight began to attract public attention, Labour MP, Jock Stallard, called for an independent inquiry to look into the question of artificial and forcefeeding with a view to discussing alternatives and 'abolishing this barbaric process' ${ }^{76}$

Keith's predicament indicates an inherent lack of sensitivity among prison medical staff towards the religious needs of prisoners from ethnic minority backgrounds while revealing the complex power relations that surrounded prison food. It also indicates that medical staff continued to define protesting prisoners as psychologically troubled, irrational, and in need of therapeutic intervention. In fact, it was not unknown for prisoners who protested against prison food to have their behaviour psychiatrically diagnosed. In 1960, Lancashire fusilier, Alan Robinson, went on hunger strike at Wellington Barracks, Bury. Alan was given discharge on medical grounds and transferred to Moston Hall Military Hospital where a psychiatrist visited him and persuaded him to eat. Alan had initially protested against the poor quality of army food. ${ }^{77}$ Prison diet formed an important part of the broader institutional nexus of power relations that structured the interactions between prisoner and prison staff. ${ }^{78}$ From the perspective of prison officials, the imposition of restricted, often meagre, food servings helped to rehabilitate behaviour by promoting personal restraint and encouraging reflection on the loss of privileges found in the outside world. Yet many prisoners refused to acknowledge the moral acceptability of meagre institutional feeding. Throughout the twentieth century, food remained a key bone of contention and provided a regular basis for prisoner protest.

The issue of physical well-being manifested in a number of other hunger strike scenarios. Many prisoners felt that prison doctors paid inadequate attention to their medical needs. Issues such as dentures could prove particularly sensitive and encourage prisoner dissent. In 1913, John Riley went on hunger strike at Dorchester Prison to protest against the slowness of the prison officials in providing him with a denture. Despite being in agonising oral pain, John was force-fed twenty-one times. ${ }^{79}$ In the early twentieth century, prisoners had to pay for medical services such as dentures. If they were not in credit, then prison staff typically ignored their problems ${ }^{80}$ Teeth problems appear surprisingly frequently in twentiethcentury prison autobiographies. ${ }^{81}$ More generally, it was common for prison doctors to disbelieve in their patient's symptoms, to presume that all prisoners were inherently dishonest and prone to malingering. ${ }^{82}$ The 
Commissioners recorded twenty-nine cases of food refusal disregarded by prison doctors as efforts to gain hospital admission (and secure a fuller diet) by feigning illness. ${ }^{83}$ Whether or not these individuals were suffering from genuine complaints, or if they staged hunger strikes to provide moral evidence of their sincerity, is unclear.

In addition, many hunger strikers sought to challenge the excessive levels of punishment which they saw as being inflicted on their bodies and minds. In the early twentieth century, prisoners could be punished-often for relatively trivial offences - with severe dietary restriction, isolated periods of solitary confinement, flogging, physical restraint, and visit reductions. Indeed, the chief aim of the convict prison system was to deter through the bureaucratic enforcement of rules and regulations. ${ }^{84}$ Prison officers themselves could be subject to punishment if they failed to report breaches of discipline, a system that encouraged staff members to maintain a punitive environment. Yet many prisoners considered the strict and complex web of prison rules pinned to the wall of their cells impossible to adhere to, and sensed that they were liable to victimisation and punishment at any given time. ${ }^{85}$

The Commissioners noted 194 prisoners who staged hunger strikes in protest against excessive punishment. In 1916, William Roberts, convicted for burglary at Manchester Prison, was force-fed fifty-five times after staging a hunger strike to protest against being punished without proper cause. ${ }^{86}$ Alfred Tragham was force-fed twenty-five times at Pankhurst after protesting against excessive punishment. ${ }^{87}$ In 1923, Thomas Clarke initiated a hunger strike in Birmingham for the reason that 'the officers are always on to him.' He agreed to resume eating upon observing the tube being prepared for his feeding. ${ }^{88}$ In 1965, Thomas Wisbey, one of the Great Train Robbers, went on hunger strike in Leeds Prison as he felt that he was being subject to harsh treatment by prison staff who were angered by a recent escape from Wandsworth made by Ronald Biggs. ${ }^{89}$ Throughout the late 1960s, Thomas staged a number of hunger strikes but called off most of these following a telephone conversation with his wife..$^{90}$ Thomas claimed that prison officials had placed him in solitary confinement for twenty-three hours a day, despite the fact that he had not been causing trouble. His brother publicly stated that 'the only way he could hit back and draw attention to what is happening was to go on hunger strike.' His solicitor added that Thomas had been a model prisoner. ${ }^{91}$ Evidently, hunger striking provided one means by which prisoners could re-assert their bodily integrity by challenging the strict punishments in 
place to impose discipline. They perceived a right to be able to reside in prisons without suffering victimisation. Yet their protests tended to be responded to with a further punishment: force-feeding.

In addition to asserting their right to health and freedom from excessive punishment, many prisoners went on hunger strike to secure certain concessions. Between 1913 and 1940, the Commissioners noted 134 hunger strikes among prisoners whose requests had been refused. Some sought transfer to an alternative prison. In 1926, John Kenny Williams, imprisoned for larceny, instigated a hunger strike after his petition to be moved to Cardiff Prison was refused. He was force-fed twelve times. ${ }^{92}$ In 1977, imprisoned singer and brothel owner, Janie Jones, went on hunger strike to protest against plans to transfer her from Holloway to Styal prison, a semi-open women's institution in Cheshire. Janie refused food for twenty-seven days until Lord Longford agreed to visit her. Her protest was predicated on the basis that she would be unable to handle her business affairs in Cheshire. ${ }^{93}$ Other protests arose for deeply personal reasons, part of an attempt to express and maintain individuality in an environment based upon conformity and a loss of identity. When, in 1933, the prison governor removed family photographs from the cell of a man in Cardiff Prison, the prisoner went on hunger strike for seventeen days and made representations to the Home Office. ${ }^{94}$ Issues relating to familial life and access to the outside world caused persistent contention. In 1969, six prisoners at Leicester Prison went on hunger strike in solidarity with four other prisoners at Durham prison who had protested against Home Office regulations that required visitors, including wives, to provide photographic identification prior to visiting category A prisoners. ${ }^{95}$

Evidently, hunger striking offered an important avenue of resistance against the rigid systems of physical and psychological control that characterised the twentieth-century prison environment. Prisoners protested for a plethora of reasons, including objections to prison food, a refusal of prison officials to meet medical or personal demands, and to rally against harsh punitive regimes. Food refusal allowed prisoners to assert their autonomy. Nonetheless, the majority of prisoner efforts to assert their perceived rights by abstaining from food were abruptly halted with force-feeding; a procedure intended (often successfully) to restore a prison regime which demanded that food was to be consumed at rigidly prescribed meal times. Prison officials tended to approach hunger striking as a behavioural issue, a problem that could be rectified by imposing physical force. Although force-feeding tended to re-align prisoner behaviour to the expected norms 
of the prison, the procedure less successfully resolved issues relating to mental health, dietary concerns, and institutional intimidation.

\section{Successful Hunger Striking}

Throughout much of the century, public attention was rarely drawn to prisoner welfare concerns apart from during well-publicised episodes of prison rioting. ${ }^{96}$ Yet a small number of force-fed prisoners did manage to capture the attention of politicians and journalists. The experience of most convict hunger strikers confirms Pethick-Lawrence's claim that hunger strikers needed firm resolution and conviction in their cause if their protests were to succeed. Prisoners also required the physical and mental resolve to withstand force-feeding. It was these prisoners who staged the most successful, newsworthy protests. Most hunger strikers, when faced with the menacing prospect of the stomach or nasal tube, chose to resume eating. Yet some prisoners did endure sustained bouts of force-feeding and tended to share particular motivations that differed from other hunger strikers. Figure 6.5 demonstrates that 166 convict prisoners went on hunger strike between 1913 and 1940 with the agenda of securing release or a sentence reduction. This prisoner group was more likely to persevere with a hunger strike and willingly submit their bodies to force-feeding. Seventeen prisoners endured over one hundred days of being force-fed as they held considerable faith in their moral cause. Between 1913 and 1915 , a prisoner at Wormwood Scrubs named Humphries instigated two hunger strikes. Humphries was force-fed 138 times (for approximately 46 days) and a further 290 times (approximately 96 days). By enduring forcefeeding, Humphries sought to demonstrate his innocence. ${ }^{97}$

The longest incidence of force-feeding recorded by the Commissioners occurred in 1935 when Henry Gordon Everett, imprisoned for attempted suicide, refused food in protest against the length of his conviction. As part of his moral crusade to secure release, Henry endured 474 feedings with a nasal tube, a period lasting approximately 15 months. ${ }^{98}$ Henry later claimed that his solicitors had encouraged him to plead guilty against his own inclination and better judgement. In a public statement made upon release, he asserted that:

In consequence of the injustice I adopted a hunger strike, continuing the same till my discharge nearly six months later ... I was kept alive by forcible-feeding, and not discharged until the last possible day of my sentence. I can bear the 
injustice no longer and also feel it my duty to register a protest against, and in defiance of, the antiquated and fallacious suicide laws which deny a poor person to die in a land of peace and plenty. ${ }^{99}$

Some decades later, Ronald John Barker commenced a particularly provocative hunger strike to draw attention to his wrongful confinement. In 1970, Ronald was sentenced to four-years imprisonment on a charge of robbing two elderly women of eighty pounds in Louth, Lincolnshire. Barker went on hunger strike at Armley Prison, Leeds, to protest his innocence. Ultimately, he endured what journalists described as a record hunger strike of 370 days (although Henry Gordon Everett's protest had in fact lasted longer). Upon being released after a successful retrial, Ronald's solicitor described him as 'a very tired, very happy man, who has to face the problem of eating normally again after being fed through a tube for 370 days' ${ }^{100}$

Everett and Barker's cases, separated by four decades, demonstrate the potential usefulness of hunger striking in challenging confinement, but only if force-feeding could be endured. Henry, who had swallowed 200 pills prior to his arrest, refuted the state's authority to dictate to him that he had no right to decide when to die. In that sense, Henry firmly believed in his innocence. Similarly, Ronald resolutely believed in his guiltlessness, a conviction that bolstered his determination to endure a lengthy period of being force-fed. Both individuals ultimately attracted public attention to their particular cases by remaining resilient and resisting coercive efforts made by prison medical staff to bring their behaviour into line. They presented their endurance of pain as itself validation of their innocence; as a necessary step taken to convince the public of their right to freedom.

Notably, at Ronald Barker's retrial, Justice McKenna advised the jury:

The accused told you on Friday that he has been on hunger strike. I would be cautious, if I were you, about concluding that the accused is innocent from his having gone on hunger strike ... many who have been rightly convicted have persisted in saying that they are innocent, and it is conceivable that such men should try to persuade others of their sincerity by refusing to eat. ${ }^{101}$

This cautious statement reflected a sense felt by judges that a long hunger strike might indeed be publicly viewed as a sign that the prisoner had repented enough or that he or she was innocent and needed to be released. The fact that a prisoner had demonstrated the conviction to 
persevere with a protest in the face of force-feeding could influence the verdict of a trial or retrial. In 1957, Alfred George Hinds was force-fed at Pentonville. MPs raised questions in the House of Commons about why Alfred appeared so willing to starve himself to death rather than accept the justice of the verdict placed upon him. Could it be that he was innocent? ${ }^{102}$ After a tenth day of force-feeding, over thirty MPs agreed that a Select Committee should inquire into the issue of whether a miscarriage of justice had taken place. ${ }^{103}$ Alfred subsequently gained notoriety and minor celebrity status after escaping from a number of high-security prisons throughout the 1960s.

The sense of injustice felt by hunger strikers depended upon the prisoner's perception of the relative seriousness of their offence which, in some instances, clashed with the mainstream views of society. In May 1976, Robert Relf staged a hunger strike in Stafford Prison. Robert, aged fifty-one, was an ex-Commando and ex-bodyguard to prominent neoNazi Colin Jordon. He had spent the 1960s, while serving as a member of the British National Socialist Movement, daubing race hate messages in Leamington Spa, including 'Integration Means Mongrelisation'. Controversially, he had also attempted to launch a British branch of the Ku Klux Klan. ${ }^{104}$ In 1976, Robert was sentenced to imprisonment for refusing to remove a racially offensive sign that advertised his house as being for sale 'to an English family only'. The sign remained in his window, overlooking a garden covered with Union Jacks. Robert was prosecuted and imprisoned under the Race Relations Act. After forty-five days of refusing to eat, Robert's protest began to receive national coverage, at which point, a judge authorised his release. Robert's supporters cheered as he left the court singing 'Rule, Britannia!'. ${ }^{105}$ During the hunger strike, Robert's wife, Sadie, regularly visited her hunger striking husband and later told friends that he was shaking and had lost a lot of weight. ${ }^{106}$ Robert's belief in his racist opinions remained firm, even if it clashed with the ethos of an increasingly multicultural society.

Numerous other prisoners staged protests that garnered publicity who did not see their crime as being wrong. Some prisoners made a stronger moral case than other. Throughout the 1960s, Rosalie Jayson commenced a ten-year harassment campaign directed at her bank manager, Bernard Hewett, after two of her cheques were dishonoured. Described by the Daily Express as 'an insoluble problem', Rosalie was continuously arrested and re-imprisoned for committing acts such as breaking 125 panes of glass at Jayson's home. Upon entering prison in 1969, she refused food in pro- 
test against injustice. ${ }^{107}$ In 1962, Russian-born celebrity health enthusiast Barbara Moore fasted in protest against being imprisoned for contempt of court. Her consultant physician, Michael Ashby, confirmed to the press that the prison doctors did not intend to feed Barbara due to her weak health (and not because of her celebrity status). The Home Office insisted that the question of force-feeding would be decided by the prison authorities. Barbara was reputed to be a breatharian (an individual who believes that humans can subsist without food and sustained soley by prana-the vital life force in Hinduism). She threatened to kill herself by holding her breath if the prison doctors tried to feed her. ${ }^{108}$ Barbara's physician, Michael Ashby of London Whittington Hospital, publicly stated that she should be allowed to carry out her threat to fast until death. In the Daily Mirror, Ashby suggested that if she dies I shall not blame myself. It may be a doctor's duty to save life, but it is also his duty not to assault a patient. To feed this patient forcibly would constitute an assault,' However Ashby believed that force-feeding would not conflict with his medical ethical inclinations if Moore lost consciousness or became too weak to protest. 'In such circumstances', he suggested, 'a patient would then not be protesting. 109

Moore's case demonstrates that it was common for the most persistent, troublesome hunger strikers to gain public notoriety. Confirming this point, earlier in the century, Inspector John Syme generated a considerable amount of public debate and paperwork for the Home Office. ${ }^{110}$ In 1909, two police constables were disciplined for having arrested and detained a number of individuals at Gerald Road Police Station, London, without sufficient evidence. Syme, who was duty officer at the time of the incidence, supported the two constables to the annoyance of his senior colleagues. A disciplinary hearing followed and Syme was punished with a transfer to Fulham Police Station. ${ }^{111}$ Perturbed at his treatment, Syme made allegations of tyranny against the chief inspector of Gerald Road, submitted insubordinate reports, and expressed his intention to carry his grievances to Parliament. At this point, Syme was dismissed from the police force. In response, he formed the National Union of Police and Prison Officers. As part of his crusade for justice, Syme also established a publication, described by his former colleagues as a 'disreputable journal', that took issue with the police commissioners and officers who disagreed with his aims of his union. ${ }^{112}$

Throughout the following decade, Syme was imprisoned numerous times for acts of civil disobedience. His plight attracted considerable public 
attention. In June 1919, in a broader discussion of whether Syme, who had gone on hunger strike and been released, would actually return to the prison under the terms of the Cat and Mouse Act, Sir John Rowlandson privately wrote that 'the John Syme case was the great cancer at the root of the present police trouble.' ${ }^{113}$ In April 1920, Syme smashed a fanlight hanging outside the residence of the prime minister. He was swiftly arrested and remanded for a week in custody at Brixton Prison before being released after six days of hunger striking. Rather than attend the police court, Syme re-committed the offence and also threatened to assault the king or queen at an opportune moment, his intention being to create a public scandal to draw attention to his grievances. ${ }^{114}$ According to a police officer who encountered Syme loitering outside the House of Commons, the ex-inspector had announced that he would go on hunger strike upon his next arrest, 'in spite of the fact that he cannot be forcibly fed due to the curious formation of his body and that he is now fully prepared to accept the alternative of death'. ${ }^{115}$

In a confidential report written in relation to an appeal made by Syme in May 1920, Chief Constables H. Morgan and J. Billings described the ex-inspector as 'a man of morose and obstinate disposition, self-opinionated and of extreme views. He was always opposed to discipline and resented its application to himself or others. His attitude was that of a person who believed the whole fabric of the empire was saturated with wrongs that wanted setting right.' The chief constables added their opinion that Syme was a 'misguided, self-deluded man who perhaps conscientiously believed he had a genuine grievance to ventilate and get put right'. ${ }^{116}$ Yet, regardless of whether Syme's views were extreme or simply posed a threat to the established structure of the police service, there is little doubt that he possessed unwavering conviction. This encouraged him to instigate a number of hunger strikes during his repeated imprisonments.

Despite force-feeding remaining relatively common in English prisons, it took a high profile case such as Syme's to ignite political and public discussion. In 1922, a heated debate took place in the House of Commons between Labour MP, Charles Ammon, and Home Secretary, Edward Shortt, on the matter. Ammon insisted that Syme was being tortured by being constantly released and re-imprisoned under the Cat and Mouse Act, an argument that echoed claims made by the suffragettes some years earlier. Referring back to the events of the previous decade, Ammon maintained that 'the passage of time has proved that the suffragettes are, after all, quite respectable members of society', adding that the torture which 
the Act had originally been directed at militant female prisoners was now being directed to individuals such as Syme who, Ammon suggested, was a respectable man who had been unjustly treated. In his curt response, Shortt stated:

The doctors say you cannot efficiently forcibly-feed him. I protest against the suggestion that we are torturing a man who deliberately persists in starving himself. We provide him, when he is in prison, with good, wholesome, tasty food. He will not touch it. That is not our fault. I protest against the suggestion that we are responsible for anything he suffers. He is absolutely responsible himself. I am told he is now hunger striking out of prison. We have no concern with that. If he does not eat out of prison, he must take the consequences himself. ${ }^{117}$

In August 1923, Syme fell ill in Pentonville while pursuing a hunger and thirst strike. Although he was temporarily released under the Cat and Mouse Act, he informed his medical officer that he intended to return to the Home Office to break another pane of glass and 'make a clean job of it'. However, Syme was too weak to leave his house. Kept under close police surveillance, Syme was re-arrested after sixteen days, after which he immediately staged a further hunger and thirst strike that lasted for eight days. In total, Syme initiated twenty-seven hunger and thirst strikes. ${ }^{118}$ Eventually, in 1925, he was transferred as a pauper lunatic to the London County Mental Hospital. ${ }^{119}$ Syme's plight provides a further example of the potential power of food refusal in drawing public and political sympathy to alleged incidences of injustice. Ultimately, Syme's wish to be re-instated to the police force proved unsuccessful. Nonetheless, in subsequent decades, Syme was informally recognised as a victim of bullying and harassment and received a police pension. ${ }^{120}$

Prisoners could also be inflamed with an unwavering conviction in a moral, rather than personal, cause. These instances also attracted public attention. In 1969, five imprisoned parents, including J. P. and Councillor Bette Bell, went on hunger strike in Winchester and Holloway after being imprisoned for protesting against increased admission charges to a public park. Their protest encouraged Chancellor of the Exchequer, James Callaghan, to order a police report into the imprisonments, an act supported by the Lord Mayor of Portsmouth and the National Council for Civil Liberties. One prisoner, Sylvia Humphreys, publicly claimed that her prison doctor had threatened to force-feed her if she continued refusing 
food although a Home Office spokesperson denied this. ${ }^{121}$ A consortium of other prisoners undertook hunger strikes as part of their broader beliefs about the prevailing socio-economic system in place in western society. These included animal rights activists (who also refused to wear prison clothes made from animal products) $)^{122}$ and language rights protestors who demanded a right to address a court in Welsh. ${ }^{123}$

Predictably, prison medical staff were prone to diagnosing prisoners whose ideologies failed to conform to those generally shared in mainstream society as mentally unstable. While force-feeding made little difference in adjusting the political ideologies and social outlook of this type of prisoner, it did help to temporarily subdue the institutional disruption which they were prone to causing. During the First World War, J. Sidney Overbury, dismissed as 'eccentric' by his prison doctor, was force-fed forty-three times at Wormwood Scrubs Prison. Overbury could not be diagnosed with a psychiatric condition severe enough to warrant asylum admission. Yet the prison doctor's labelling of eccentricity suggests that he perceived, or chose to present, his patient's decision to refuse food as a product of psychological instability, a problem requiring rectification with a stint of force-feeding to bring the prisoner's behaviour into line. ${ }^{124}$

Overbury was imprisoned with Tom Ferris. Both were members of a small group of families who had lived closely together in Beeston, Yorkshire, who subsisted on the profits of a cottage knitting industry. ${ }^{125}$ The Beeston Brotherhood was constituted on Tolstoyian Christian anarchist principles that rejected the principle of state authority. Accordingly, when Overbury and Ferris were initially imprisoned in 1915 for distributing leaflets in contravention of Regulation 27, they both refused to eat prison food on the basis that it had been purchased with institutional, and by extension, state funds. Both Overbury and Ferris rejected the principle of taxation and viewed prison food as property stolen from the financial resources of the population. After a number of days of correspondence between the Commissioners and prison officials, Ferris conceded to eat food but only if it had been prepared by his wife and if permission was granted for him to continue writing his book on religious principles while imprisoned. Under-Secretary of State in the Home Office, Edward Troup, granted permission on medical (psychiatric) grounds. ${ }^{126}$ The prison governor looked upon Ferris as suicidal - as a 'religious maniac' and privately discussed the possibility of certifying him with members of the Home Office. ${ }^{127}$ Lord Leonard Courtney entered into the debate by 
adding 'get them out of hospital as soon as possible in the hope that the episode may die a natural death'. ${ }^{128}$

Police re-arrested Overbury in the following year for disobeying orders. Upon refusing food, he was force-fed. The medical officer described Overbury as insane but doubted the possibility of being able to certify him during such a short term of imprisonment. In a letter written to Brigadier General Childs, he stated 'the man is undoubtedly a religious crank or maniac and I should say there was no possibility of making a soldier of him. I suggest that it is worth considering whether it would not be wiser to let him alone when he is released and not persevere with him. ${ }^{129}$ In June 1925, Ferris re-appeared in Leeds Prison after being convicted of assaulting a police officer at a public meeting. He was visibly suffering from kidney disease, cardiac problems, and oedematous ankles that pitted on pressure. Despite his ailments, Ferris declared a hunger strike, adding that this time 'it will either be release or death'. On this occasion, Ferris insisted that he would not eat food obtained from anywhere, not even from his wife. He was swiftly released under the Cat and Mouse Act and no attempt was made to re-arrest him and enforce the sentence. ${ }^{130}$

In 1929, both Overbury and Ferris were once again sent to prison after being prosecuted for building a house for themselves without planning permission (which the two individuals did not recognise). Ferris, described in the medical report as 'old for his age, somewhat edentulous and the heat sounds are a little impure', refused food on the basis that he would not obey man-made laws that demanded obedience to the state. The prison Governor Hugh Emerson considered Ferris to be unfit for force-feeding. ${ }^{131}$ Nonetheless, Overbury was repeatedly force-fed despite suffering persistent vomiting. On one occasion, the prison doctor caught Overbury with his fingers lodged down his throat. Closer supervision confirmed that Overbury's vomiting was mostly natural, not self-induced. The medical officer decided against further feedings as the persistent subjection to the procedure was exhausting the ageing Overbury, rendering the exercise futile. ${ }^{132}$

Force-feeding was a procedure with high disciplinary value. While some doctors undoubtedly believed that it helped to save lives, it seems likely that they also recognised the value of feeding technologies in helping to restore prison order and discipline prisoners. If hunger striking was cast as a behavioural problem, then force-feeding appeared to provide a solution. Yet prison doctors encountered a significant number of individuals who were determined to withstand force-feeding due to a firm conviction in 
beliefs, including their own personal innocence, anarchism, breatharianism, and right-wing racism. Although small in number, these prisoners were particularly disruptive and often garnered media interest.

\section{CONCLUSION}

It seems clear that force-feeding did not disappear from prison medical practice following the end of the suffragette and Irish republican campaigns. On the contrary, and despite the controversial death of Thomas Ashe in 1917, prison doctors continued to tackle food refusal with stomach and nasal tubes throughout much of the century. The relatively widespread use of force-feeding remained mostly unnoticed outside of the prison walls. When pursuing hunger strikes alone, most convict prisoners could not amass the support of their fellow prisoners or the general public. Suffragettes and Irish republicans had efficient propagandistic mechanisms that rapidly conveyed news of force-feeding to an interested public. Lacking a supportive network, and relatively isolated from the outside world, convict prisoners tended to pursue unsuccessful hunger strikes unless they possessed enough determination to withstand forcefeeding. Accordingly, force-feeding remained mostly hidden from view; a disciplinary act performed in the private world of the prison deemed so normal in an intrinsically punitive environment that it barely passed comment. Notably, their intervention swiftly eradicated the majority of prisoner hunger strikes, suggesting the punitive nature of force-feeding and prison medicine itself. The records of convict prisoners strongly suggest that force-feeding was not solely used to save lives and preserve health. Although the procedure may well have had some health benefits, it undoubtedly held coercive, punitive value.

\section{Notes}

1. Stafford Smith, Bad Men, p. 214.

2. See discussion in Kew, PCOM7/355, 'Letter Relating to Death of William Edward Burns', 15 March 1918.

3. 'Fatal Hunger Strike: Death in Gaol of Man who Imitated Suffragists at Holloway', Daily Mirror (8 October 1913), p. 4.

4. 'Register of Criminal Prisoners on Hunger Strike'.

5. Vernon, Hunger, pp. 60-80.

6. For recent discussion of prisoner rights and the erosion of staff power, see John R. Hepburn, 'The Erosion of Authority and the Perceived 
Legitimacy of Inmate Social Protest: A Study of Prison Guards', Journal of Criminal Justice, 12:6 (1984), pp. 579-90.

7. 'Register of Criminal Prisoners on Hunger Strike'.

8. Flynn, Pawns in the Game, p. 37

9. Seán McConville, 'The Victorian Prison: England, 1865-1965', in Norval Morris and David J. Rothman (eds), The Oxford History of the Prison: The Practice of Punishment in Western Society (Oxford: Oxford University Press, 1995), pp. 117-50.

10. For the rise of the nineteenth-century prison, see Michael Ignatieff, $A$ Just Measure of Pain: The Penitentiary in the Industrial Revolution, 1750-1850 (London: Macmillan, 1978); Philip Priestley, Victorian Prison Lives: English Prison Biography, 1830-1914 (London: Pimlico, 1999 [1985]).

11. Michel Foucault, Discipline and Punish: The Birth of the Prison (London: Penguin, 1977 [1975]).

12. Ibid., p. 8 .

13. Ibid., p. 11.

14. Sim, Medical Power in Prisons, p. 278.

15. Emmeline Pethick-Lawrence, 'Hunger Strikers: The Ordeal of the Imprisoned Suffragettes', Manchester Guardian (8 November 1929), p. 22.

16. Kew, PCOM7/355, 'Letter Relating to Death of William Edward Burns', 15 March 1918.

17. Kew, PCOM7/355, 'Circular from the Prison Commission', undated.

18. Murphy, Political Imprisonment and the Irish, p. 99.

19. Leigh v Gladstone.

20. Kew, CO859/19/7, 'Feeding of Prisoners on Hunger Strike', $1939-40$.

21. Kew, PCOM7/355, 'Forcible Feeding: Methods, Treatment as Hospital Patients', undated.

22. Sim, Medical Power in Prisons, pp. 63-4.

23. Ibid., p. 66. For dual loyalty, see Beverly A. Smith, 'The Irish Prison System-Men in the Middle, 1865-90', Medical History, 26:4 (1982), pp. 371-94.

24. Sim, Medical Power in Prisons, pp. 86-93.

25. Richard R. Prewer, 'The Contribution of Prison Medicine', in Louis Blom-Cooper (ed.), Progress in Penal Reform (Oxford: Clarendon Press, 1974), pp. 116-128 on pp. 127-8.

26. J. C. Spencer, 'Problems in Transition: From Prison to Therapeutic Community', in Paul Halmos (ed.), Sociological Studies in the British Penal Services (Keele: University of Keele, 1965), pp. 13-30.

27. Anthony Babington, The Power to Silence: A History of Punishment in Britain (London: Robert Maxwell, 1968), p. 189. 
28. Hobhouse and Brockway, English Prisons Today; Prison Medical Reform Council, Prison Medical Service: Report of an Enquiry Conducted by Roger Page into the Medical Service of H. M. Prisons (London: Prison Medical Reform Council, 1943).

29. Sim, Medical Power in Prisons, p. 74.

30. Hobhouse and Brockway, English Prisons Today, pp. 267-8 and p. 278.

31. Mary Gordon, Penal Discipline (London: Routledge and Sons, 1922), pp. $\mathrm{x}$-xi.

32. Gordon, Penal Discipline, p. xi.

33. Kew, HOl44/21930, 'Prisons and Prisoners: Forcible Feeding of Prisoners on Hunger Strike-Hunger Strike of Frederick Bowman; Question of Forcible Feeding', 24 March 1944.

34. 'Miss Todd's Hunger Strike Ended', Times (15 February 1972), p. 1.

35. Foucault, Discipline and Punish, p. 16.

36. J. P. Masterton, H. A. F. Dudley and Sheila MacRae, 'Design of Tube Feeds for Surgical Patients', British Medical Journal, ii (October 12 1963), pp. 909-13 on p. 909.

37. William Henry Butter Stoddart, Mind and its Disorders: A Textbook for Students and Practitioners of Medicine (London: H. K. Lewis, 1926), p. 542.

38. Robert Henry Cole, Mental Diseases: A Textbook of Psychiatry for Medical Students and Practitioners (London: University of London Press, 1924), pp. 311-12.

39. Prisoner bed numbers collated from Report of the Commissioners of Prisons and the Directors of Convict Prisons, with Appendices, for 1912-13, Reports of Commissioners, 1914, [Cd. 7092, 7093], xlv.i and Report of the Commissioners of Prisons and Directors of Convict Prisons for the Years 1939-41, Reports of Commissioners, 1945-6, [Cmd. 6820], xiv. 281.

40. 'His Majesty's Prisons (Medical Officers)', House of Commons Debates (23 February 1921), vol. 138 col. 983W. For discussion of the use of force-feeding in prisons with full-time medical staff, see Kew, PCOM7/355, 'Letter to Under-Secretary of State', 14 March 1919.

41. Report of Commissioners of Prisons and Directors of Convict Prisons for the Years 1939-41, pp. 61-2; Sim, Medical Power in Prisons, p. 75.

42. 'Register of Criminal Prisoners on Hunger Strike'.

43. Ibid.

44. Ibid.

45. T. Claye Shaw, 'The Psychology of the Militant Suffragette', Lancet, 181 (17 May 1913), p. 1415; Elaine Showalter, The Female Malady: Women, Madness and English Culture, 1830-1980 (New York: Penguin, 1987 [1985]), pp. 162-4. 
46. Martin J. Weiner, 'The Health of Prisoners and the Two Faces of Benthamism', in Richard Creese, William F. Bynum and Joe Bearn (eds), The Health of Prisoners: Historical Essays (Amsterdam: Rodopi, 1995), pp. 44-58 on p. 46; Ian Miller, 'Constructing Moral Hospitals: Childhood Health in Irish Reformatories and Industrial Schools, c.1851-1890', in Anne Mac Lellan (ed.), Growing Pains: Childhood Illness in Ireland, 1750-1950 (Dublin: Irish Academic Press, 2013), pp. 105-22.

47. Sim, Medical Power in Prisons, pp. 60-2.

48. Ibid., p. 68.

49. Ibid., p. 69.

50. See, for instance, Ruggles-Brise, English Prison System, pp. 198-215.

51. 'Register of Criminal Prisoners on Hunger Strike'.

52. Ibid.

53. Ibid.

54. Ibid.

55. 'Suicide in Prison', Irish Times (2 January 1907), p. 7.

56. 'Prisoners (Suicides)', House of Commons Debates (19 December 1968), vol. 775 cols $443-4$.

57. Philip Priestley, Victorian Prison Lives: English Prison Biography, 1830-1914 (London: Pimlico, 1999 [1985]), pp. 180-4.

58. 'Prisons (Suicide and Insanity)', House of Commons Debates (11 July 1922), vol. 156 cols 1040-1; Weiner, Reconstructing the Criminal, p. 353.

59. Hobhouse and Brockway, English Prisons Today, p. 556; Alison Liebling and Tony Ward, 'Prison Doctors and Prison Suicide Research', in Creese, Bynum and Bearn (eds), Health of Prisoners, pp. 118-33 on pp. 120-1.

60. 'Steinie Morrison Dies in Prison', Irish Times (26 January 1921), p. 4.

61. Priestley, Victorian Prison Lives, p. 172.

62. Ignatieff, A Just Measure of Pain, p.72.

63. Priestley, Victorian Prison Lives, p. 158.

64. 'Register of Criminal Prisoners on Hunger Strike'.

65. Ibid.

66. Miller, Reforming Food in Post-Famine Ireland, pp. 74-8; Miller, 'Food, Medicine and Institutional Life', pp. 207-15.

67. Evelyn Ruggles-Brise, The English Prison System (London: Macmillan and Co., 1921), p. 189. For discussion of prison weight gain and loss, see Ciara Breathnach, 'Medical Officers, Bodies, Gender and Weight Fluctuation in Irish Convict Prisons, 1877-95', Medical History, 58:1 (January 2014), pp. 67-86.

68. Hobhouse and Brockway, English Prisons Today, pp. 126-30. 
69. 'Prison (Diet)', House of Commons Debates (5 April 1944), vol. 398 cols 2008-9; 'Our Prison System', Lancet, 246 (4 August 1945), pp. 145-6; 'H. M. Prisons in the War Years: Report for 1942-4', British Medical Journal, i (8 March 1947), pp. 304-5.

70. Sim, Medical Power in Prisons, p. 94.

71. 'Prisons, Borstals and Detention Centres (Diet Changes)', House of Commons Debates (7 May 1959), vol. 605 cols 68-9.

72. 'Leicester Prison', House of Commons Debates (6 November 1972), vol. 845 cols $67-8$.

73. Fenner Brockway, Inside the Left: Thirty Years of Platform Press Prison and Parliament (London: Allen and Unwin, 1942), p. 91.

74. Ibid., p. 111.

75. '819 Day Hunger Strike Ordeal: M. P.s Told of Ordeal in a British Jail', Daily Mirror (30 January 1974), p. 1.

76. 'Prisoner (Artificial Feeding)', House of Commons Debates (30 January 1974), vol. 868 cols $441-5$.

77. 'Hunger Striker Leaves Army: Medical Grounds', Guardian (14 April 1960), p. 24.

78. John Coveney, Food, Morals and Meaning: The Pleasure and Anxiety of Eating, $2^{\text {nd }}$ edn. (London: Routledge, 2006 [2000]), pp. 65-75.

79. 'Register of Criminal Prisoners on Hunger Strike'.

80. Sim, Medical Power in Prisons, p. 71.

81. Corder Catchpool, Letters of A Prisoner: For Conscience Sake (London: George Allen and Unwin, 1941), p. 48, p. 56, p. 75, p. 77, p. 93.

82. Prison Medical Reform Council, Prison Medical Service, pp. 3-4; Priestley, Victorian Prison Lives, p. 177; Weiner, Reconstructing the Criminal, p. 126.

83. 'Register of Criminal Prisoners on Hunger Strike'.

84. Leon Radzinowicz and Roger Hood, A History of English Criminal Law and its Administration from 1750 (London: Stevens, 1986), pp. 628-9.

85. Hobhouse and Brockway, English Prisons Today, pp. 231-45; Priestley, Victorian Prison Lives, p. 197.

86. 'Register of Criminal Prisoners on Hunger Strike'.

87. Ibid.

88. Ibid.

89. 'Those who have not Escaped', Guardian (19 July 1965), p. 8.

90. 'Wisbey Ends Eleven-Day Hunger Strike', Times (26 July 1965), p. 6.

91. 'Robbers Switched', Daily Express (17 July 1965), p. 1.

92. 'Register of Criminal Prisoners on Hunger Strike'.

93. 'Janie Jones in Gaol Protest', Guardian (16 March 1977), p. 5.

94. 'Hunger Strike in Cardiff Gaol: Family Photographs', Manchester Guardian (23 September 1933), p. 11. 
95. 'Riot Gaol Hunger Strike', Times (15 November 1969), p. 2.

96. Alyson Brown, Inter-war Crime and Penal Policy in England: The Dartmoor Convict Prison Riot, 1932 (Basingstoke: Palgrave Macmillan, 2013).

97. 'Register of Criminal Prisoners on Hunger Strike'.

98. Ibid.

99. 'Protest against Suicide Laws: Man's Letter to Police', Manchester Guardian (13 December 1938), p. 16.

100. 'Hunger-Strike Man Freed', Guardian (3 February 1971), p. 1.

101. Ibid, p. 1.

102. 'Alfred George Hinds (Forcible Feeding)', House of Commons Debates (4 July 1957), vol. 572 col. 1291.

103. 'The Hinds Case: Thirty M. P.s Call for Inquiry', Manchester Guardian (6 July 1957), p. 1.

104. 'The Black Man's Burden', Daily Mirror (19 May 1976), p. 3.

105. 'That Notice Stays Up, Says Freed Race Rebel', Daily Express (22 June 1976), p. 2.

106. 'Move in Race Case', Guardian (26 May 1976), p. 1.

107. 'It's Back to Jail for a Window Breaker', Daily Express (12 November 1969), p. 7.

108. 'Dr Moore not to be Forcibly-Fed: Consultant's Promise', Guardian (15 May 1962), p. 3.

109. 'When Dr Babs Will be Given Food', Daily Mirror (15 May 1962), p. 2.

110. Joseph F. King, 'The Foundations of Police Unionism in the United Kingdom: The Case of Inspector John Syme', Law Enforcement Executive Forum (March 2011), pp. 173-87.

111. V. L. Allen, 'The National Union of Police and Prison Officers', Economic History Review, 11:1 (August 1958), pp. 133-43.

112. Kew, MEPO3/838, 'Report on Case of John Syme', 28 May 1920.

113. Kew, MEPO3.838, 'Letter to General Sir Nevil Macready from Sir John Rowlandson', 14 June 1919.

114. Kew, MEP3/838, 'Letter from John Syme to Gernal Horwood, Police Commissioner', 26 April 1920.

115. Kew, MEPO3/838, 'Letter from George Wood', 19 May 1920.

116. 'Report on Case of John Syme'.

117. 'Wireless Broadcasting', House of Commons Debates (4 August 1922), vol. 157 cols $1951-75$.

118. Kew, MEPO2/10202, 'Hunger Strikes by Syme; Releases from Prison under 'Cat and Mouse' Act: Prisoners (Temporary Discharge for Ill Health) Act 1913', August 1923.

119. Kew, MEPO3/1844, 'John Syme: Transfer to Criminal Lunatic Asylum and Epsom Mental Hospital', 25 May 1925. 
120. 'Ex-Inspector Syme (Widow)', House of Commons Debates (11 March 1948), vol. 448 cols 1552-6.

121. 'Hunger Strike in Gaol', Guardian (22 July 1969), p. 1.

122. 'Visiting Ban on Hunger Striker', Guardian (29 March 1975), p. 5.

123. The Times (19 December 1972), p. 2.

124. 'Register of Criminal Prisoners on Hunger Strike'.

125. Charlotte Alston, Tolstoy and his Disciples: The History of an International Movement (London and New York: I. B. Tauris, 2014), p. 224.

126. Kew, HOl44/20983, 'Memorandum', 18 December 1915.

127. Kew, HOl44/20983, 'Transcript of Telephone Conversation with the Governor of Leeds Prison', 18 December 1915.

128. Kew, HOl44/20983, 'Memorandum from Lord Courtney', 28 December 1915.

129. Kew, HO 144/20983, 'Letter to Brigadier General Childs', 30 October 1916.

130. Kew, HO 144/20983, 'Letter from Leeds Prison to Home Office', 9 June 1925.

131. Kew, HO 144/20983, 'Letter from Hugh Emerson to Home Office', 5 July 1930.

132. Kew, HO 144/20983, 'Letter from Hugh Emerson to Home Office', 14 July 1930. tion and reproduction in any medium or format, as long as you give appropriate credit to the original author(s) and the source, provide a link to the Creative Commons license and indicate if changes were made.

The images or other third party material in this chapter are included in the work's Creative Commons license, unless indicated otherwise in the credit line; if such material is not included in the work's Creative Commons license and the respective action is not permitted by statutory regulation, users will need to obtain permission from the license holder to duplicate, adapt or reproduce the material. 